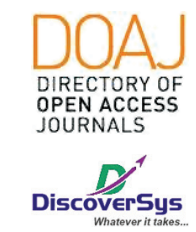

Published by DiscoverSys

\section{Seorang penderita kanker paru dengan manifestasi efusi perikardium: Laporan kasus}

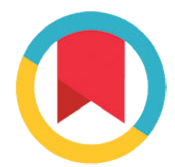

CrossMark

\author{
Ida Ayu Nanda Dwijayanthi, ${ }^{1 *}$ Ida Bagus Sutha ${ }^{2}$
}

\title{
ABSTRACT
}

Background: Based on WHO data, lung malignancy is the most common cause of death in patients with cancer. On the other hand, $10-20 \%$ of metastasis involves pericardium. Pericardial effusion is associated with variety of underlying heart diseases, malignancies, infections and complications of cardiovascular procedures. However, in some cases, MPE may manifest to cardiac tamponade which cause collapse of cardiovascular system and will eventually lead to death.

Case description: We reported 51 years old male patient with chief complain of shortness of breath especially when lying down. Patient has history of the same complaints and had done pericardiocentesis in the past. Patient were now hospitalized with severe pericardium effusion post-cardiocentesis and stage IV pulmonary malignancy. Biopsy showed that the patient had squamous cell carcinoma.
Two weeks after the lung biopsy, patient's condition worsened and patient eventually passed away. Patient was planned to have paclitaxel-carboplatin chemotherapy after biopsy. Pericardium effusion is associated with cardiac metastases, which most often originate from lung malignancy. There are four mechanism of pericardial metastasis, such as direct extension, through blood vessel, lymphatic vessel and through intracavity diffusion either through cava vein or pulmonary vein. Cardiac tamponade is a life-threatening complication caused by accumulation of excessive fluid which cause extracardial compression and haemodynamic instability. Therefore, pericardiocentesis is needed as an emergency and life-saving procedure.

Conclusion: Chemotherapy may increase the survival rate of patients with MPE.

Keywords: Squamous cell carcinoma, Malignant Pericardium Effusion, Pericardial Efussion

Cite This Article: Dwijayanthi, I.A.N., Sutha, I.B. 2020. Seorang Penderita Kanker Paru Dengan Manifestasi Efusi Perikardium: Laporan Kasus. Intisari Sains Medis 11(2): 590-596. D0I: 10.15562/ism.v11i2.591

\section{ABSTRAK}

Latar belakang: Data WHO menunjukan bahwa kanker paru merupakan penyebab kematian utama akibat keganasan dimana angka insiden keganasan yang melibatkan metastasis pada pericardium sekitar 10-20\%. Efusi perikardium sering dihubungkan dengan berbagai macam penyakit seperti penyakit jantung, keganasan, infeksi dan sebagai komplikasi prosedur tindakan kardiovaskuler. Pada beberapa kasus metastasis jantung dapat bermanifestasi menjadi tamponade jantung sehingga menyebabkan kolaps sistem kardiovaskuler yang dengan cepat dapat menyebabkan kematian.

Deskripsi kasus: Kami melaporkan seorang pasien laki-laki berusia 51 tahun dengan keluhan sesak nafas terutama berbaring. Pasien sudah mengalami keluhan yang sama berulangkali dan telah dilakukan perikardiosintesis. Saat ini pasien dirawat dengan efusi perikardium berat post-kardiosentesis dengan keganasan paru stadium IV dengan hasil biopsi karsinoma sel skuamosa. Pasien mengalami perburukan

dan meninggal dua minggu setelah biopsi paru. Seharusnya setelah dilakukan biopsi paru, pasien direncanakan untuk menjalani kemoterapi paclitaxel-carboplatin. Efusi pericardium sering dikaitkan dengan proses metastase jantung dimana penyebabnya paling banyak berasal dari keganasan pada paru. Penyebaran tumor ke jantung dapat melalui empat jalur yaitu secara langsung (direct extension), melalui pembuluh darah, melalui sistem limfe dan melalui difusi intrakavitas baik melalui vena kava maupun vena pulmonaris. Komplikasi yang sering terjadi adalah tamponade jantung yaitu suatu kondisi mengancam jiwa yang disebabkan oleh akumulasi cairan yang terlampau banyak sehingga menyebabkan kompresi ekstrakardial dan gangguan hemodinamik yang membahayakan sehingga diperlukan perikardiosentesis sebagai tindakan emergensi.

Kesimpulan: Pemberian kemoterapi dapat memberikan peningkatan angka kesintasan pasien.

\section{*Korespondensi:}

Ida Ayu Nanda Dwijayanth, Program Studi Pendidikan Dokter Spesialis Penyakit Dalam, Fakultas Kedokteran Universitas Udayana/RSUP Sanglah, Denpasar, Bali, Indonesia nandadwijayanthi@yahoo.com

Diterima: 27-08-2019

Disetujui: 11-05-2020

Diterbitkan: 01-08-2020
Kata kunci: Karsinoma sel skuamousa, efusi perikardal maligna, efusi pericardium

Cite Pasal Ini: Dwijayanthi, I.A.N., Sutha, I.B. 2020. Seorang Penderita Kanker Paru Dengan Manifestasi Efusi Perikardium: Laporan Kasus. Intisari Sains Medis 11(2): 590-596. D0l: 10.15562/ism.v11i2.591

\section{PENDAHULUAN}

Terdapat peningkatan insiden kanker pada negaranegara berkembang. WHO melaporkan bahwa 60\% dari total kasus kanker di dunia terjadi di Afrika, Asia, Amerika Tengah dan Amerika Selatan. 
Daerah-daerah tersebut menyumbang $70 \%$ kasus kematian karena kanker, yang diperburuk dengan keterlambatan diagnosis dini dan kesulitan akses kesehatan. ${ }^{1}$

Pada tahun 2012, angka penderita kanker di seluruh dunia naik menjadi sekitar 14 juta kasus baru per tahun. Angka ini diperkirakan akan meningkat menjadi 22 juta per tahun dalam dua dekade mendatang. Selama periode yang sama, kematian akibat kanker diperkirakan meningkat dari 8,2 juta setiap tahun menjadi 13 juta per tahunnya. Secara global, pada tahun 2012 kanker yang paling umum didiagnosis adalah kasus paru ( 1,8 juta kasus; $13,0 \%$ dari total), payudara ( 1,7 juta; $11,9 \%$ dari total), dan usus besar (1,4 juta; $9.7 \%$ dari total). Dimana angka kematian kanker tertinggi disebabkan oleh kanker paru (1,6 juta, 19,4\% dari total), liver (0,8 juta, 9,1\%), dan abdomen ( 0,7 juta; $8,8 \%)$. Data WHO menunjukan bahwa kanker paru merupakan keganasan yang menjadi penyebab kematian utama pada kelompok kematian akibat keganasan, bukan hanya pada laki-laki tetapi juga pada perempuan. ${ }^{1,2}$

Salah satu komplikasi yang dapat ditemukan pada pasien dengan kanker paru adalah efusi pericardium. Selain itu, efusi perikardium juga dihubungkan dengan penyakit jantung, infeksi dan sebagai komplikasi prosedur tindakan kardiovaskuler. Sebuah penelitian menunjukkan bahwa angka insiden keganasan yang melibatkan pericardium sekitar $10-20 \%$. Di pusat perawatan tersier, keganasan menjadi penyebab paling sering efusi perikardium dan tamponade jantung. Penelitian lain menyebutkan bahwa $43,8 \%$ dari insiden efusi perikaridum diakibatkan oleh keganasan. ${ }^{3,4}$

Efusi pericardium maligna (EPM) seringkali bersifat asimtomatik. Namun pada beberapa kasus dapat bermanifestasi menjadi tamponade jantung sehingga menyebabkan kolaps sistem

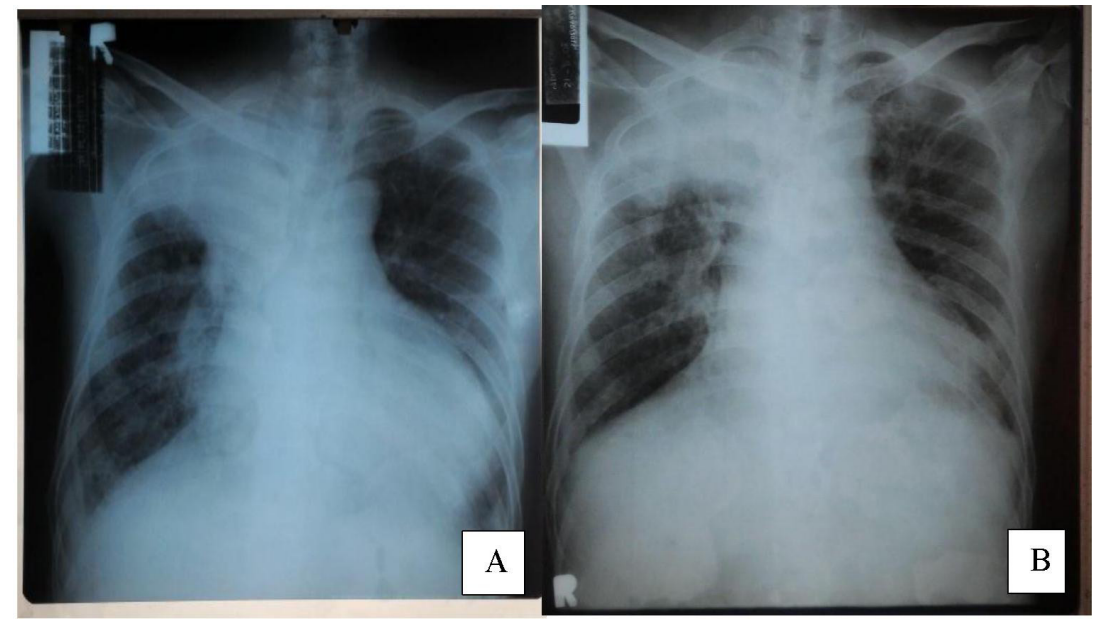

Gambar 1 Foto rontgen torak pasien: A. waktu datang; B. foto satu minggu sebelum masuk rumah sakit kardiovaskuler yang dengan cepat dapat menyebabkan kematian. Sebuah laporan kasus berseri yang mengikutsertakan beberapa pasien kanker dalam satu dekade terakhir menyebutkan bahwa efusi perikardium akibat keganasan dikaitkan dengan rekurensi dan prognosis yang buruk. Beberapa studi lain menyebutkan bahwa keganasan pada paru menjadi penyebab utama efusi perikardium terkait keganasan.,

Efusi perikardium terkait keganasan memerlukan terapi yang optimal dan harus mempertimbangkan efektivitas pengobatan dengan harapan hidup. Meskipun manajemen pasien EPM yang tepat waktu dapat mengurangi risiko kematian, banyak pasien memiliki komorbiditas utama yang terkait dengan penyakit metastasis luas, penurunan kualitas hidup dan kelangsungan hidup. Dalam beberapa kasus efusi perikardium yang tidak berhubungan dengan keganasan memiliki angka kesintasan yang lebih baik. ${ }^{3}$ Pada laporan kasus ini akan melaporkan pasien dengan efusi perikardium berulang yang diduga berhubungan dengan karsinoma paru.

\section{LAPORAN KASUS}

Pasien merupakan seorang laki-laki berusia 51 tahun yang dirawat dengan keluhan utama sesak napas selama dua minggu terakhir yang memburuk saat tidur berbaring. Pasien juga mengeluhkan batuk sejak empat bulan yang lalu dengan dahak berwarna putih, nyeri dada, penurunan nafsu makan menurun dan penurunan berat badan sekitar $14 \mathrm{~kg}$ dalam tiga bulan terakhir.

Tiga bulan yang lalu pasien pernah dirawat di rumah sakit dengan keluhan yang sama dan didiagnosis dengan efusi pericardium. Pasien kemudian dilakukan perikardiosentesis dan didapatkan total cairan sebanyak $3000 \mathrm{cc}$ berwarna kemerahan. Pasien mengalami perbaikan klinis setelah dilakukan tindakan. Tiga minggu kemudian pasien kembali merasakan keluhan yang sama dan dilakukan tindakan perikardiosentesis dengan total cairan keluar kurang lebih $2700 \mathrm{cc}$ berwarna kemerahan. Pasien dicurigai dengan keganasan pada paru.

Pasien datang dalam keadaan sadar, tekanan darah 130/70 mmHg, nadi $94 \mathrm{kali} / \mathrm{menit}$, frekuensi pernapasan $32 \mathrm{kali} / \mathrm{menit}$ dansuhu aksila $36^{\circ} \mathrm{C}$. Pasien tampak sesak namun tidak didapatkan peningkatan JVP. Pada daerah leher, ditemukan pembesaran kelenjar getah bening regional pada leher kanan, diameter $2 \mathrm{~cm}$, mobile, kenyal dan tidak nyeri. Pada pemeriksaan dada didapatkan pelebaran batas jantung. Saat dilakukan pemeriksaan perkusi ditemukan suara redup pada lapang paru kanan atas. Hasil foto rontgen dada terdapat kardiomegali bila dibandingkan foto rontgen 


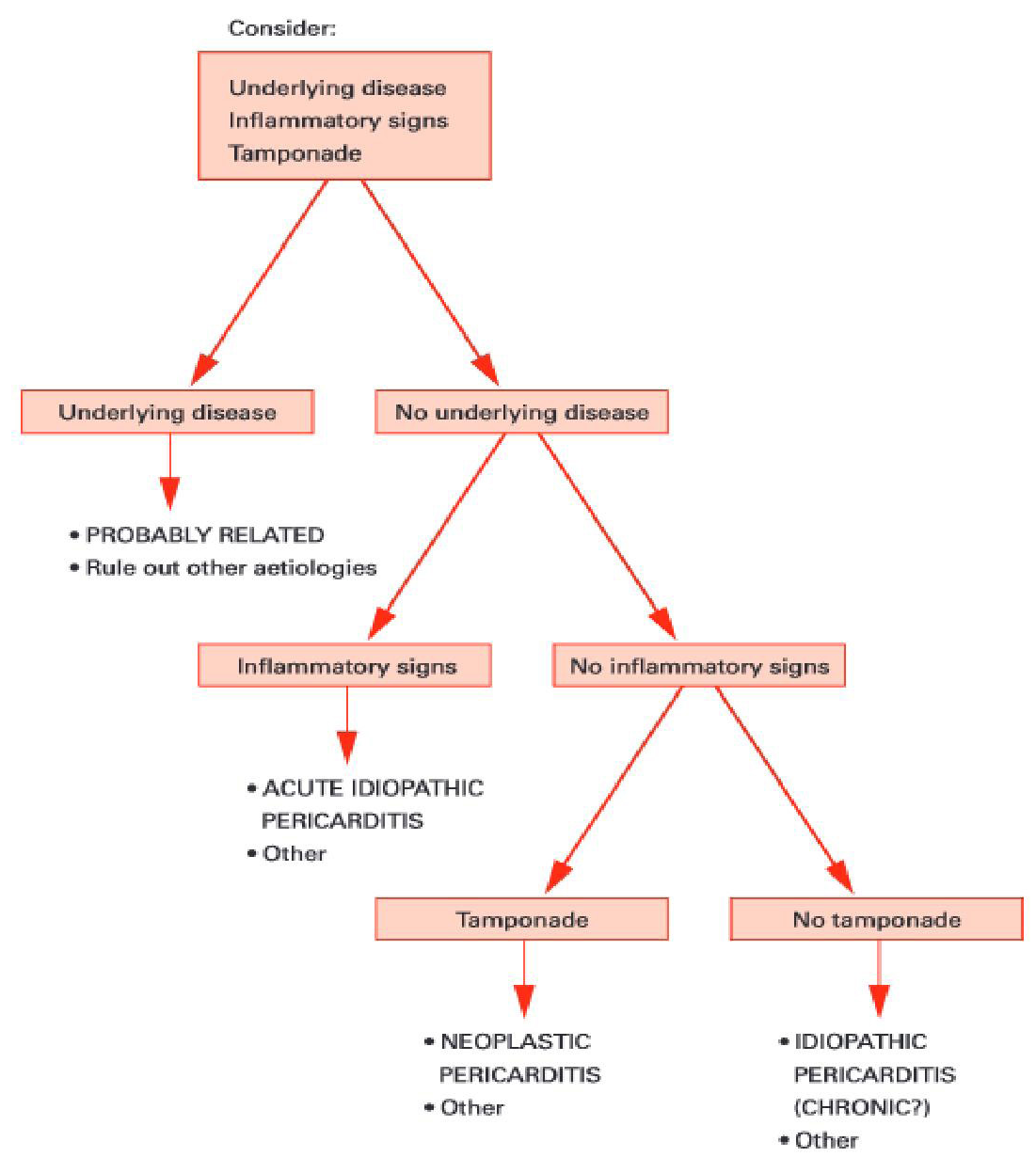

Gambar 1 Pendekatan awal untuk menentukan etiologi dari efusi perikardium $^{8}$

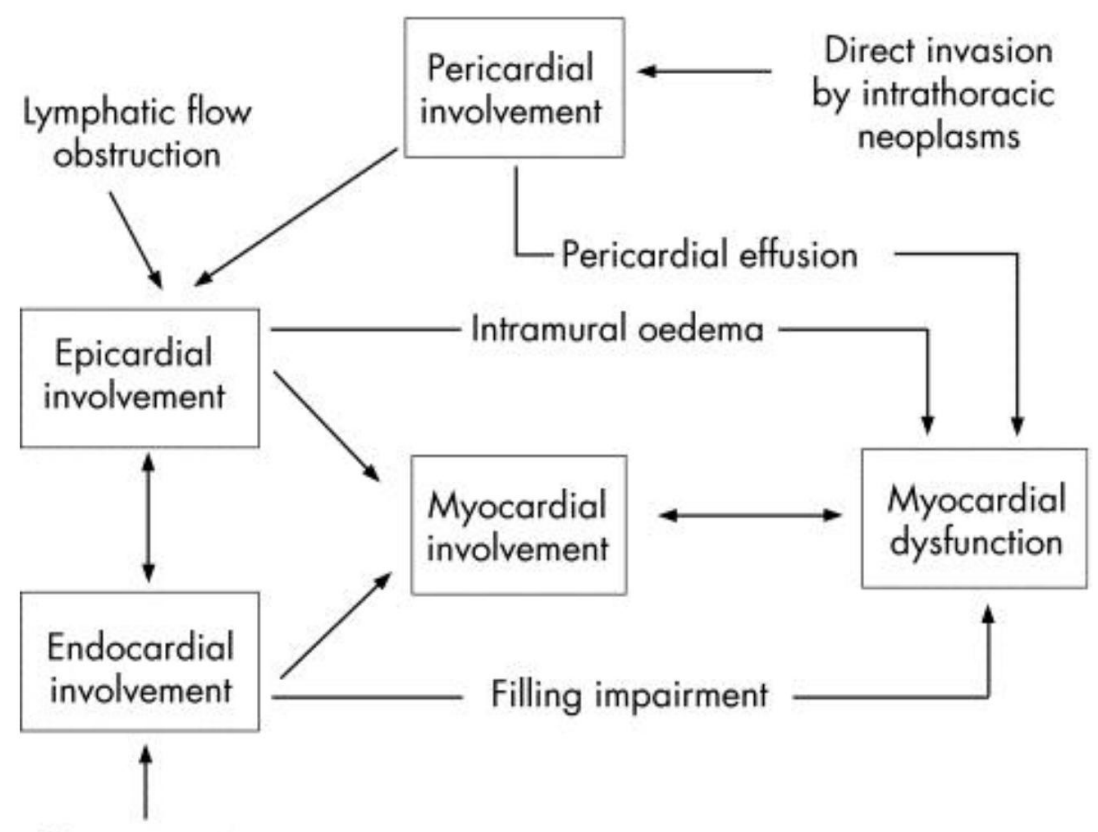

\footnotetext{
Direct invasion

by intravascular

neoplasms
}

Gambar 2 Patofisiologi mekanisme metastase di jantung menyebabkan disfungsi jantung sebelumnya serta adanya opasitas homogen di paru kanan atas yang diduga massa.

Pada pemeriksaan ekokardiografi didapatkan efusi perikardium berat $(2,3 \mathrm{~cm})$ dengan penurunan fungsi diastolik ventricular kiri dan ejection fraction (EF) 63\%. Dari perikardiosentesis didapatkan cairan total berjumlah $420 \mathrm{cc}$ berwarna merah yang kemudian dilakukan pemeriksaan sitologi akan tetapi tidak ditemukan adanya sel ganas.

Pasien kemudian dilakukan pemeriksaan diagnostik paru yaitu trans-thoracal biopsy (TTB) dengan hasil karsinoma sel skuamosa. Sedangkan untuk pembesaran kelenjar di leher dilakukan tindakan fine needle aspiration biopsy (FNAB) dengan kesimpulan metastase suatu karsinoma. Pasien direncanakan untuk menjalani kemoterapi kombinasi paclitaxel-carboplatin. Akan tetapi pasien mengalami perburukan dan kemudian meninggal.

\section{DISKUSI}

Efusi perikardium adalah penumpukan cairan abnormal dalam ruang perikardium. Cairan dapat berupa transudat, eksudat, pioperikardium atau hemoperikardium. Efusi perikardium merupakan hasil perjalanan klinis suatu penyakit. Gejalanya bersifat tidak spesifik dan berkaitan dengan penyakit yang mendasarinya. Akumulasi yang abnormal ini selanjutnya dapat menyebabkan tamponade jantung, yaitu suatu kondisi mengancam jiwa yang disebabkan oleh akumulasi cairan yang terlampau banyak sehingga menyebabkan kompresi ekstrakardial dan gangguan hemodinamik. ${ }^{5}$ Efusi perikardium pada keganasan ditemukan pada 5-15\% kasus. Efusi perikardium maligna seringkali bersifat asimtomatis, dengan insiden $10-20 \%$ ditemukan saat postmortem. Namun pada beberapa kasus dapat bermanifestasi menjadi tamponade jantung sehingga menyebabkan kolapsnya sistem kardiovaskuler. ${ }^{3,6}$ Penelitian yang dilakukan oleh Gornik, dkk, terhadap 219 pasien, didapatkan 43.8\% etiologi efusi perikardium dikaitkan dengan keganasan melalui hasil pemeriksaan sitologi positif, dengan penyakit dasar yang paling sering ditemukan berupa keganasan paru $(34,4 \%)$ dan kanker payudara $(16,7 \%){ }^{4}$

Beberapa kasus, efusi perikardium dihubungkan dengan kondisi sebelumnya yaitu adanya penyakit jantung yang mendasari. Pasien dengan efusi perikardium dengan sebab yang belum jelas, jika ditemukan adanya tanda-tanda inflamasi merupakan prediksi dari perikarditis idiopatik akut, sedangkan efusi pericardium berat tanpa ada tanda-tanda inflamasi dan tamponade dapat diprediksi suatu kondisi efusi perikardium idiopatik kronik. Tamponade jantung tanpa tanda-tanda 
inflamasi merupakan kondisi efusi perikardium yang diakibatkan oleh keganasan. ${ }^{8}$

Beberapa studi menyatakan bahwa hipoksia sebagai salah satu mekanisme terjadinya metastase kanker. Studi tersebut menyebutkan bahwa diantara banyak bentuk sel tumor, sel punca dari kanker memiliki fenotipe yang sangat mengancam. Banyak faktor dari lingkungan mikro tumor memainkan peranan penting pada perkembangan fenotipe yang mematikan tersebut, termasuk diantaranya adalah adanya paparan pada kondisi hipoksia. Beberapa sel punca kanker bersifat agresif, tumorigenik yang dapat merespon langsung terhadap kondisi kekurangan oksigen. Selain itu, hipoksia juga menciptakan suasana yang mendukung dan mempertahankan lingkungan niche untuk sel punca sehingga mampu untuk menginvasi organ maupun jaringan yang lainnya. ${ }^{9}$

Jantung dapat menjadi tempat metastase dari sel neoplasma maligna yang menyebar dari tempat jauh. Insiden metastase jantung yang pernah dilaporkan berada diantara 2,3\% dan 18,3\%. Metastase jantung itu sendiri didefinisikan sebagai penyebaran jauh sel tumor ke setiap struktur yang membentuk jantung (pericardium, epicardium, myocardium, endocardium, pembuluh darah besar dan arteri koroner), serta tumor yang mempengaruhi rongga jantung atau memproduksi trombus neoplastik intrakavitas. ${ }^{10}$

Tumor dapat menyebar ke jantung melalui empat jalan alternatif:

1. Secara langsung (direct extension)

2. Melalui pembuluh darah

3. Melalui sistem limfe

4. Melalui difusi intrakavitas baik melalui vena kava maupun vena pulmonaris

Sistem limfatik memainkan peranan utama metastasis jantung. Pada kasus metastasis jantung terjadi hambatan aliran limfatik intramural oleh emboli neoplastic sehingga getah bening akan stagnan dan didaerah hulu miokardium akan terjadi obstruksi yang kemudian mengakibatkan gangguan drainase sistem limfatik endokardial ke epikardial baik total maupun sebagian. Hal ini menyebabkan kerusakan jaringan akibat stasis nodus limfatik dan edema, sehingga meningkatkan proliferasi sel neoplastik didaerah yang terhambat dan daerah aliran retrograde yang memungkinkan penyebaran infiltrasi sel metastase. Sebagai hasil dari peningkatan tekanan, dinding limfatik juga bisa pecah sehingga menyebabkan penyebaran tumor interstitial. ${ }^{10}$

Ketika sel-sel neoplastik terlibat didalam sistem limfatik, kontraksi miokard memiliki efek ganda baik menghalangi dan maupun mendukung terjadinya metastasis jantung dimana kontraktilitas di satu sisi menghambat penyebaran metastasis tumor intramural dengan memfasilitasi getah bening dan drainase darah. Akan tetapi di sisi lain hal ini membantu sel-sel neoplastik menyebar sepanjang permukaan epikardial. ${ }^{10}$

Beberapa tumor yang mengakibatkan metastase jantung dari paru adalah adenokarsinoma (21\%) dan karsinoma sel skuamosa (18,2\%). Pada penyakit metastase jantung $2 / 3$ kasus melibatkan pericardium (69,4\%), 1/3 melibatkan epikardium $(34,2 \%)$ dan miokardium $(31,8 \%)$, serta hanya $5 \%$ pada endokardium. Jenis tumor yang paling sering melibatkan perikardium adalah mesothelioma dan karsinoma paru disamping ovarium, lambung dan prostat. ${ }^{10}$

Pada penyakit keganasan paru, proses metastase berdasarkan tipe histologi menyebutkan bahwa tipe adenokarsinoma menyebar ke jantung pada $26 \%$ kasus, karsinoma sel skuamosa sebanyak 23,4\% kasus, undifferentiated carcinoma sekitar 21,2\% dan tipe bronkoalveolar 17,4\%. Untuk seluruh jenis tipe histologi karsinoma paru yang metastasis ke jantung paling banyak melibatkan pericardium (82,2\% adenocarcinoma, $72,4 \%$ karsinoma sel skuamosa dan $67,2 \%$ undifferentiated carcinoma). Karsinoma sel skuamosa lebih sering metastasis ke lapisan epikardium $(41,4 \%) .^{10}$

Sebuah penelitian yang dilakukan Wang dkk, terhadap 86 pasien efusi perikardium didapatkan data adenokarsinoma $(\mathrm{n}=54)$, karsinoma sel skuamosa $(\mathrm{n}=11)$, NSCLC $(\mathrm{n}=5)$; poorly differentiated carcinoma $(\mathrm{n}=5)$; large cell carcinoma $(\mathrm{n}=1)$; bronchoalveolar cell carcinoma $(\mathrm{n}=1)$; mixed adenosquamous carcinoma $(\mathrm{n}=2)$; mixed adenocarcinoma and large cell carcinoma $(\mathrm{n}=1)$; mixed adenocarcinoma and small cell carcinoma $(\mathrm{n}=1)$; dan mixed squamous cell carcinoma and small cell carcinoma $(n=1) .{ }^{11}$

Berdasarkan penelitian yang dilakukan oleh Bussani, dkk, terdapat perbedaan insiden metastase jantung pada laki-laki (46\%) dan wanita (31,7\%). Insiden tumor primitif menurun berdasarkan usia yaitu $16,8 \%$ pada pasien usia $\leq 64$ tahun dan $4,9 \%$ pada pasien usia $>85$ tahun. Tumor-tumor yang menunjukkan insiden metastase ke jantung yaitu pleural mesothelioma (48,4\%), melanoma (27,8\%), adenokarsinoma paru (21\%), undifferentiated carcinoma (19,5\%), karsinoma sel skuamosa paru $(18,2 \%)$ dan kanker payudara (15,5\%).

Efusi perikardium dapat bersifat asimtomatis apabila pertambahan cairan berjalan perlahan. Pemeriksaan ekokardiografi dapat digunakan untk menentukan ukuran efusi, yaitu: ${ }^{8,10}$

1. Sedikit (echo-free space saat diastolik $<10 \mathrm{~mm}$ )

2. Sedang (minimal $\geq 10 \mathrm{~mm}$ di posterior) 


\begin{tabular}{lcc}
\hline & \multicolumn{2}{c}{ Pasien } \\
\cline { 2 - 3 } & No. & $\%$ \\
\hline Cancer-related & & \\
Definitely malignant & 60 & 27.4 \\
Likely malignant & 27 & 12.3 \\
Post-XRT & 2 & 0.9 \\
\hline
\end{tabular}

3. Banyak ( $\geq 20 \mathrm{~mm})$,

4. Sangat banyak ( $\geq 20 \mathrm{~mm}$ dengan kompresi jantung)

Perikarditis neoplasma 40 kali lebih sering disebabkan oleh keganasan sekunder daripada primer, lebih sering disebabkan oleh kanker paru, kanker payudara, melanoma maligna, limfoma, dan leukemia. Diagnosis didasarkan pada temuan sitologi cairan perikardium dan biopsi perikardial/ epikardial. Sitologi cairan perikardium positif pada 75-87\% kasus dan biopsi perikardial positif pada $27-65 \%$ pasien dengan keganasan perikardium. ${ }^{13}$ Studi yang dilakukan Gornik, dkk, menyatakan bahwa sitologi cairan pericardium positif dengan ditemukannya sel ganas pada $28,6 \%$, hingga $54,1 \%$ kasus pada pasien dengan keganasan aktif atau dengan riwayat kanker., ${ }^{4,8}$

Pemeriksaan cairan sitologi perikardium sangat membantu untuk menegakkan diagnosis dengan spesifitas $100 \%$ tapi memiliki sensitivitas yang bervariasi. Hasil sitologi positif pada pasien kanker berkisar antara 57-100\%. Beberapa peneliti berpendapat bahwa nilai negatif pada sitologi cairan perikardium tidak mengeliminasi keganasan, ditunjukkan dengan hasil $42-62 \%$ pasien dengan gejala pericardial akan tetapi hasil sitologi pada cairan pericardium negatif. ${ }^{4}$

Efusi perikardium maligna merupakan komplikasi yang paling ditakuti. Gejala yang muncul bergantung pada sisi mana yang paling banyak terlibat. Efusi perikardial karena perikarditis neoplasma ditandai dengan hemoragik dan paling sering disebabkan oleh kerusakan dinding kapiler akibat lepasnya substansi inflamasi dan oleh hiperdilatasi dari lumen pembuluh darah karena kongesti. ${ }^{8}$

Secara klinis dapat ditemukan peningkatan tekanan sistem vena, hipotensi, pulsus paradoksus, takikardi, dispneu atau takipneu dengan paru normal. Gambaran foto rontgen dada didapatkan pembesaran siluet jantung dengan paru normal, atau didapatkan gambaran jantung bottle-shaped. ECG dapat normal atau perubahan non spesifik pada gelombang ST-T, electrical alternans, bradikardi, electromechanical dissociation (agonal phase). ${ }^{8,14}$
Terapi non-spesifik untuk efusi pericardium meliputi: ${ }^{13,15}$

1. Perikardiosentesis terapeutik Tindakan ini merupakan tindakan darurat pada tamponade jantung. Disini dapat dipasang pig tail cathether selama 2-3 hari. Selama itu pasien harus diberikan antibiotika. Perikardiotomi subxiphoidea dapat dilakukan dibawah anestesi lokal dengan angka kekambuhan sekitar 6-12\%.

2. Pembuatan pericardial window

Tindakan ini memerlukan torakotomi dan dilakukan drainase dari kavum perikardium ke kavum pleura dengan angka kekambuhan sekitar 5-20\%.

3. Perikardiodesis

Dilakukan pemberian tetrasiklin, thiothepa atau bleomisin ke dalam kavum perikardium untuk melengketkan perikardium. Tetrasikin $500 \mathrm{mg}$ dalam $25 \mathrm{ml}$ salin dimasukkan dalam 2-3 menit atau bleomisin 30 unit dalam $20 \mathrm{ml}$ salin.

4. Perikardiektomi

Pada prosedur ini sebagian besar perikardium diangkat sehingga angka kekambuhan kecil. Akan tetapi angka mortalitas dan morbiditas lebih besar. Perikardiektomi terutama dilakukan pada perikarditis konstriktif.

Penelitian yang dilakukan oleh Cormican dan Nyman menunjukkan bahwa drainase dan instilasi dengan menggunakan bleomicin (intrapericardial belomycin) mencegah episode lanjut dari efusi perikardium. Bleomicin $5 \mathrm{mg}$ dalam $20 \mathrm{ml}$ air dimasukkan ke dalam kantung perikard (intraperikardial), kemudian diklem dan dibuka 24 jam kemudian. ${ }^{17}$ Beberapa agen lain untuk instilasi adalah nitrogen mustard, radioactive gold, 5-fluorouracil, dan tetrasiklin. Saat ini obat yang paling kecil efek toksiknya untuk mengatasi efusi ganas adalah tetrasiklin dan bleomicin. Instilasi dengan bleomicin dari 6 dari 8 pasien tidak terjadi rekurensi dan reakumulasi efusi terjadi di 14 hari pada satu pasien dan yang lain terjadi 2-5 bulan kemudian. ${ }^{17}$

Studi lain menyatakan bahwa pemberian Cisplatin intraperikardial memberikan hasil yang baik dalam mengurangi terjadinya reakumulasi cairan dibandingkan dengan Tetrasiklin dan 5-fluorourasil. Cisplatin diberikan $10 \mathrm{mg}$ dalam $20 \mathrm{ml}$ normal salin dimasukkan (instilasi) ke dalam rongga perikard dalam 5 menit selama 1-5 hari berturut-turut dengan dosis maksimal $50 \mathrm{mg}$. Efek positif terapi ini mencapai 15/16 kasus (93-8\%). ${ }^{18}$

Terapi kanker sendiri bergantung pada stadiumnya. Terapi NSCLC stadium IV, dengan status 
Tabel 1 Etiologi efusi perikardium pada 219 pasien $^{4}$

\begin{tabular}{|c|c|c|}
\hline \multirow[b]{2}{*}{ Keganasan } & \multicolumn{2}{|c|}{ Patients } \\
\hline & No. & $\%$ \\
\hline Lung & 33 & 34.4 \\
\hline Breast & 16 & 16.7 \\
\hline Leukemia/myelodysplastic syndrome & 9 & 9.4 \\
\hline Cancer of unknown primary & 8 & 8.3 \\
\hline Esophagus & 5 & 5.2 \\
\hline Sarcoma & 5 & 5.2 \\
\hline Mesothelioma & 4 & 4.2 \\
\hline Lymphoma/lymphoproliferative disorder & 4 & 4.2 \\
\hline Colorectal & 4 & 4.2 \\
\hline Other $^{*}$ & 8 & 8.3 \\
\hline Total & 96 & 100.0 \\
\hline
\end{tabular}

Table 2 Penyakit-penyakit kegansan yang mendasari 96 pasien efusi perikardium terkait keganasan ${ }^{4}$

\begin{tabular}{lcc}
\hline & \multicolumn{2}{c}{ Pasien } \\
\cline { 2 - 3 } & No. & $\%$ \\
\hline Cancer-related & 60 & 27.4 \\
Definitely malignant & 27 & 12.3 \\
Likely malignant & 2 & 0.9 \\
Post-XRT & 7 & 3.2 \\
Post-BMT & 96 & 43.8 \\
Total & & \\
Cancer-unrelated & 38 & 17.4 \\
Post CT Surgery & 20 & 9.1 \\
Iatrogenic & 7 & 3.2 \\
Rheumatologic & 5 & 2.3 \\
Post MI & 2 & 0.9 \\
Infectious & 1 & 0.5 \\
Trauma & 50 & 22.8 \\
Indeterminate & 123 & 56.2 \\
Total & 219 & 100 \\
Total & & \\
\hline
\end{tabular}

performance dari ECOG 0, 1 dan mungkin juga 2 dapat diberikan kemoterapi. Pilihan untuk pemberian cisplatin atau karboplatin lebih dapat diterima dan dapat dikombinasikan dengan obat sitotoksik generasi ketiga (docetaxel, gemcitabine, irinotecan, paclitaxel, pemetrxed dan vinorelbine). Bukti menunjukkan bahwa kombinasi cisplatin mempunyai respon yag lebih baik dibandingkan carboplatin dan dapat meningkatkan angka harapan hidup bila dikombinasi dengan obat sitotoksik generasi ketiga. Efek samping mual, nefrotoksik dan neurotoksik lebih jarang ditemukan paa Carboplatin dibandingkan cisplatin. Selain itu, cisplatin lebih sering menyebabkan trombositopenia. ${ }^{19}$

Sebuah studi mengenai hubungan antara karsinoma paru dan tamponade jantung menyatakan bahwa angka kesintasan pasien tidak terkait dengan usia, jenis kelamin, histologi, metastasis kelenjar getah bening, metastasis jauh, efusi pleura, gejala, tanda klinis, temuan EKG, atau drainase awal efusi. Selain itu, pada pasien dengan NSCLC dan tamponade jantung, hasil sitologi cairan pericardium tidak mempengaruhi angka kesintasan pasien. Kemoterapi sistemik dapat meningkatkan angka kesintasan pasien. ${ }^{3}$

\section{RINGKASAN}

Kami melaporkan kasus seorang pasien laki-laki berusia 51 tahun yang dirawat dengan efusi pericardium berat post kardiosentesis dan keganasan paru stadium IV dengan hasil biopsi karsionam sel skuamosa. Pasien direncanakan untuk menjalani kemoterapi dengan paclitaxel-carboplatin, akan tetapi pasien mengalami perburukan dan meninggal dua minggu setelah biopsi paru. Efusi pericardium merupakan proses metastase jantung yang paling sering ditemukan dan biasanya disebabkan oleh proses keganasan paru. Komplikasi yang sering terjadi adalah tamponade jantung yaitu suatu kondisi mengancam jiwa yang disebabkan oleh akumulasi cairan yang terlampau banyak sehingga menyebabkan kompresi ekstrakardial dan gangguan hemodinamik sehingga memerlukan penanganan segera berupa perikardiosentesis. Pemberian kemoterapi dapat memberikan meningkatkan angka kesintasan pasien.

\section{DAFTAR PUSTAKA}

1. WHO. Global battle against cancer won't be won with treatment alone:Effective prevention measures urgently needed to prevent cancer crisis. International Agency for Research on Cancer. London, 2014.

2. Perhimpunan Dokter Paru Indonesia. Kanker paru: Pedoman diagnose \& penatalaksanaan di Indonesia. 2003.

3. Cruza, AP, Garzab CV, Avilab BT, Torresa J, et al. Effectiveness and prognosis of initial pericardiocentesis in the primary management of malignant pericardial effusion. Interact CardioVasc Thorac Surg (2010) 11 (2): 154161. doi: 10.1510/icvts.2010.232546.

4. Gornik HI, Herman MG, Beckman JA. Abnormal cytology predicts poor prognosis in cancer patients with pericardial effusion. American Society of Clinical Oncology. J Clin Oncol (2005) 23:5211-5216.

5. Roswati E,dan Safri Z. Perikardiosentesis pada efusi perikardium masif. CDK-202/ 2013: 40(3):192-196.

6. Gumrukcuoglu HA, Odabasi D, Akdag S, Ekim H. Management of cardial tamponade: a comparative study between echo-guided pericardiocentesis and surgery A report of 100 patients. Cardiol Res Pract. 2011; 2011: 197838.

7. Fidler, Isaiah J. The Pathogenesis of cancer metastasis: the 'seed and soil' hypothesis revisited. Nature Review Cancer 3, 453-458. 2003, doi: 10.1038/nrc 1098. 
8. Soler JS, Sauleda JS, Miralda GP., Jordi Soler-Soler. General pericardiology: Management of pericardial effusions. Heart 2001; 86: 230-245.

9. Semenza GL. Hypoxia-inducible factors: mediators of cancer progression and targets for cancer therapy. Trends Pharmacol Sci. 2012;33(4):207-214.

10. Bussani R, De-Giorgio F, Abbate A, Silvestri F. Cardiac metastase. J Clin Pathol. 2007; 60 (1): 27-34.

11. Wang PC, Yang KY, Chao JY, et al. Prognostic role of pericardial fluid cytology in cardiac tamponade associated with non-small cell lung cancer. Chest. 2000;118(3):744-9.

12. Wilkes JD, Fidias P, Vaickus L, Peres RP. Malignancyrelated pericardial effusion; 127 cases from the Roswell Park Cancer Institue. Cancer 1995, 2015;76(8):1377-87.

13. Sagristà-Sauleda J, Mercé J, Permanyer-Miralda G, SolerSoler J. Clinical clues to the causes of large pericardial effusions. Am J Med. 2000;109(2):95-101.

14. Maisch B, Ristic AD. Practical aspect of the management of pericardial disease. Heart 2003; 89: 1096-1103.

15. Maisch B, Chairperson*, Seferovic PM, et al. Guidelines on the diagnosis and management of pericardial disease -Full Text: The task force on the diagnosis and management of pericardial disease of the European society of cardiology. Eur Heart J, 2004.
16. Cruz GA, Garza CV, Avilab BT, et al. Effectiveness and prognosis of initial pericardiocentesis in the primary management of malignant pericardial effusion. Interact CardioVasc Thorac Surg (2010) 11 (2): 154-161.

17. Cormican MC dan Nyman CR. Intrapericardial bleomycin for the management of cardiac tamponade secondary to malignant pericardial effusion. Br Heart J 1990; 63: 61-2.

18. Maisch B, Ristic AD, Pankuweit S, et al. Neoplastic pericardial effusion; Efficacy and safety of intrapericardial treatment with cisplatin. Eur Heart J, 2002; 23: 1625-1631.

19. Azzoli CG, Baker S, Temin S, et al. American society of clinical oncology clinical practice: guideline update on chemotherapy for stage IV non-small cell lung cancer. American Society of Clinical Oncology. JCO, 2009; 27(36): 6251-6266.

20. Laham RJ, Cohen DJ, Kuntz RE, et al. Pericardial effusion in patients with cancer: outcome with contemporary management strategies. Heart, 1996; 75: 67-71.

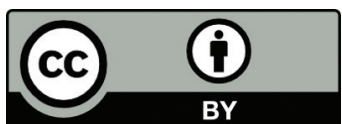

This work is licensed under a Creative Commons Attribution 